\title{
HMGA2 regulates acute myeloid leukemia progression and sensitivity to daunorubicin via Wnt/ß-catenin signaling
}

\author{
SHUO YANG ${ }^{1,2}$, YUELI GU ${ }^{2}$, GENJIE WANG $^{2}$, QINGZHU HU ${ }^{2}$, \\ SHUXIA CHEN ${ }^{2}$, YONG WANG ${ }^{3}$ and MINGFENG ZHAO ${ }^{4}$

\begin{abstract}
${ }^{1}$ First Center Clinic College of Tianjin Medical University, Tianjin 300192; Departments of ${ }^{2}$ Hematology and ${ }^{3}$ Cardiology, The First People's Hospital of Shangqiu, Shangqiu, Henan 476100; ${ }^{4}$ Department of Hematology,

Tianjin First Center Hospital, Tianjin 300192, P.R. China
\end{abstract}

Received December 18, 2018; Accepted May 9, 2019

DOI: $10.3892 /$ ijmm.2019.4229

\begin{abstract}
Acute myeloid leukemia (AML) is a malignant disease with an increasing prevalence in adults and children. However, valuable molecular diagnostic research is rare. In the present study, plasmids silencing and overexpressing high-mobility group AT-hook 2 (HMGA2) were respectively transfected in HL60 and NB4 cells. The effects of HMGA2 on AML cell viability, apoptosis, migration and invasion were determined by preforming MTT, flow cytometry, wound scratch and Transwell assays, respectively. Genes associated with apoptosis and Wnt signaling were evaluated by reverse transcription-quantitative (RT-q)-PCR and western blotting. AML cell sensitivity to daunorubicin (DNR) and the regulatory effects of the Wnt signaling pathway via HMGA2 following treatment with the agonist $\mathrm{LiCl}$ or antagonist XAV939 were detected by MTT, RT-qPCR and western blot analysis. The results revealed that the expression of HMGA2 was elevated more so in HL60, KG1, U937, Kasumi-1, THP-1 and K562 cells than in NB4 cells. Silencing HMGA2 suppressed cell viability, migration and invasion, enhanced cell apoptosis and sensitivity to DNR, and almost restored the DNR inhibitory function that was promoted by $\mathrm{LiCl}$ treatment. In addition, low expression of HMGA2 attenuated X-linked inhibitor of apoptosis and Bcl-2 mRNA and protein levels, and upregulated the expression of Bax and cleaved-caspase-3. Furthermore, silencing HMGA2 not only decreased Wnt and non-phospho- $\beta$-catenin expressions, but also partially reversed the increased expressions of these proteins induced by $\mathrm{LiCl}$ treatment. On the other hand, overexpression of HMGA2 exhibited the opposite results after transfection in NB4 cells. The results of the present study demonstrated that
\end{abstract}

Correspondence to: $\mathrm{Dr}$ Mingfeng Zhao, Department of Hematology, Tianjin First Center Hospital, 24 Fu Kang Road, Nankai, Tianjin 300192, P.R. China

E-mail: mingfe_mfezhao@163.com

Key words: high-mobility group AT-hook 2, acute myeloid leukemia, daunorubicin, progression, Wnt/ $\beta$-catenin
HMGA2 played important roles in driving AML progression and chemosensitivity in HL60 and NB4 cells, potentially by activating the $\mathrm{Wnt} / \beta$-catenin signaling pathway. Therefore, it was suggested that HMGA2 may be a promising molecular marker for AML diagnosis.

\section{Introduction}

Leukemia is a malignant disease characterized by the abnormal growth of hematopoietic stem cells. According to the American Cancer Society and the National Cancer Institute in 2016, 468,000 patients were diagnosed with leukemia in the United States (1). As one of the most common blood tumors in adult leukemia, acute myeloid leukemia (AML), which is characterized by abnormal proliferation and the accumulation of a large number of unusual hematopoietic stem cells in bone marrow, peripheral blood and even in other tissues, could result in the destruction of the hematopoietic system, and the morbidity and mortality of the disease has exhibited an annual increase $(1,2)$. At present, cell-dependent therapy, hepatocyte transplantation, targeted therapy, chemotherapy and radiotherapy have been applied for the treatment of leukemia under different circumstances (3-6). In regard to induction therapy for AML, the main chemotherapy regimen has been the combination of anthracyclines and cytarabine for the past three decades (7). Although a recent multicenter clinical phase III trial revealed that the complete remission rate of patients with AML could be as high as $79 \%$, the overall survival and relapse-free survival were only 20 and 15 months, respectively (8). Therefore, relapse of drug resistance is still a leading cause of mortality in patients with AML, and it is also a major issue in the attempt to maintain longer survival times after initial remission (9).

The etiology of AML is very complex, and current research has indicated that chromosomal abnormalities and reproducible genetic abnormalities were the main mechanisms of morbidity in patients with AML (10-12). High mobility group A2 (HMGA2), a member of the high mobility group protein superfamily, is widely accepted as a new oncogene $(13,14)$. HNGA2 has the physiological functions of inducing gene transcription, integrating retrovirus 
into chromosomes, inducing transformation and promoting the activation of cancer cells; it also plays an important role in maintaining stem cell differentiation potential and self-renewal ability (15-17). Based on the high expression of HMGA2 at the embryonic stage, the association between HMGA2 and stem cells was studied. We previously reported that the expression of HMGA2 was high in embryonic stem cells and its expression gradually decreased with age (18). Meyer et al (19) suggested that the level of HMGA2 was increased in the CML-accelerated and CML-blastic phases, when compared with that in the CML-chronic phase. Furthermore, the expression of HMGA2 was negatively correlated to let-7b $(19,20)$. In addition, HMGA2 could accelerate the $\mathrm{G} 2 / \mathrm{M}$ phase of cell cycle transformation or induce epithelial-mesenchymal transition to promote tumorigenesis, invasion and metastasis $(16,21)$.

However, the role of HMGA2 in AML and the underlying mechanism are still unclear. Several signaling pathways have been reported to be important in the progression of leukemia including the Wnt/ $\beta$-catenin, PI3K/Akt/mTOR, NF- $\kappa \mathrm{B}$ and Janus kinase/STAT signaling pathways (22-25). The aim of the present study was to investigate the $\mathrm{Wnt} / \beta$-catenin signaling pathway in regulation of HMGA2 in AML cells.

\section{Materials and methods}

Cell culture. The human myeloid leukemia cell lines, NB4, HL60, KG1, U937, Kasumi-1, THP-1 and K562 were purchased from American Type Culture Collection. All cells were cultured at $37^{\circ} \mathrm{C}$ in $5 \% \mathrm{CO}_{2}$ atmosphere in RPMI-1640 medium (Gibco; Thermo Fisher Scientific, Inc.) containing with $10 \%$ fetal bovine serum (FBS; Thermo Fisher Scientific, Inc.), $100 \mathrm{U} / \mathrm{ml}$ penicillin and streptomycin (North China Pharmaceutical Co., Ltd.).

NB4 and HL60 cells were selected to conduct the following experiments. Both cell lines were treated with $10 \mu \mathrm{g} / \mathrm{ml}$ daunorubicin (DNR; Shenzhen Main Luck Pharmaceuticals Inc.) for $24 \mathrm{~h}$ at $37^{\circ} \mathrm{C}$ to evaluate the cell sensitivity to DNR. In addition, NB4 and HL60 cells were treated with $10 \mu \mathrm{M}$ XAV939 (MedChemExpress USA), or $10 \mu \mathrm{M}$ XAV939 + $10 \mu \mathrm{g} / \mathrm{ml}$ DNR and $20 \mathrm{mM} \mathrm{LiCl}$ (Sigma Aldrich; Merck KGaA), or $20 \mathrm{mM} \mathrm{LiCl}+10 \mu \mathrm{g} / \mathrm{ml} \mathrm{DNR}$ for $24 \mathrm{~h}$ at $37^{\circ} \mathrm{C}$ to perform mechanism-related experiments.

Cell transfection. HL60 and NB4 cells, with or without drug treatments, were respectively seeded in 6-well plates $\left(1.0 \times 10^{5}\right)$ for $24 \mathrm{~h}$ at $37^{\circ} \mathrm{C}$ before transfection. Silencing HMGA2 [small interfering RNA (siRNA/si-) HMGA2; forward, 5'-AGA UUGAGAUUGAAAGUGCCU-3' and reverse, 5'-GCA CUUUCAAUCUCAAUCUCU-3'], overexpressing HMGA2 (HMGA2) and negative control (NC) plasmids $(5 \mu \mathrm{g} /$ well of each plasmid) were synthetized by Invitrogen (Thermo Fisher Scientific, Inc.). Lipofectamine 2000 ${ }^{\mathrm{TM}}$ (Invitrogen; Thermo Fisher Scientific, Inc.) was applied to determine transient transfection according to manufacturer's protocol. siHMGA2, siNC, HMGA2 or NC and Lipofectamine $2000^{\mathrm{TM}}$ were respectively added to Opti-Minimum Essential Medium (MEM; Gibco; Thermo Fisher Scientific, Inc.) medium. The Lipofectamine/siRNA or Lipofectamine/overexpressing RNA mixtures were cultured at $20^{\circ} \mathrm{C}$ for $10 \mathrm{~min}$ and then
Opti-MEM RPMI-1640 medium was added. After $6 \mathrm{~h}$ of culture, the media was changed back to RPMI-1640 medium containing $10 \%$ FBS. After 24 h culture, cells were used in the subsequent experiments.

Cell viability. Cell viability was determined using a 3-(4, 5-dimethylthiazol-2-yl)-2, 5 diphenyltetrazolium bromide (MTT; Beyotime Institute of Biotechnology) assay. After transfection or treatment with drugs for 24,48 or $72 \mathrm{~h}$, $5 \times 10^{3}$ cells per well were seeded into 96 -well plates and cultured at $37^{\circ} \mathrm{C}$ with $5 \% \mathrm{CO}_{2}$. Subsequently, $10 \mu 1 \mathrm{MTT}$ was added into each well containing culture medium for a further $1 \mathrm{~h}$. Then, $100 \mu \mathrm{l}$ DMSO was added to dissolve crystals once the media was removed. The optical density values were detected using a Microplate Reader (Thermo Fisher Scientific, Inc.) at $490 \mathrm{~nm}$.

Wound scratch and Transwell assays. Cells $\left(5 \times 10^{4}\right)$ were seeded in 12-well plates and incubated at $37^{\circ} \mathrm{C}$ for $24 \mathrm{~h}$. A sterile pipette tip $(10 \mu \mathrm{l})$ was used to draw a wound in the center of the plate. The plates were gently washed 3 times with PBS. Then, the cells were cultured in serum-free medium for 0 or $48 \mathrm{~h}$. The scratch area was measured using ImageJ software version 1.8.0 (National Institutes of Health).

The invasion activity of cells was detected using a 24-well transwell chamber coated with Matrigel (Corning, Inc.). After $24 \mathrm{~h}$ of transfection treatment, the cells were resuspended in serum-free medium and $1 \times 10^{5}$ cells were added into the coated upper chamber. RPMI-1640 medium containing 10\% FBS was added to the lower chamber and the cells were incubated for $48 \mathrm{~h}$ at $37^{\circ} \mathrm{C}$ in an environment with a $5 \% \mathrm{CO}_{2}$. The cells were fixed with $4 \%$ formaldehyde for $20 \mathrm{~min}$ at $25^{\circ} \mathrm{C}$ and stained with $1 \%$ crystal violet for a further $15 \mathrm{~min}$ at $37^{\circ} \mathrm{C}$. The number of invading cells was counted at x200 magnification using a light microscope.

Flow cytometry. Transfected cells $\left(5 \times 10^{5}\right)$ were digested with $0.25 \%$ trypsin and centrifugated at $1,000 \mathrm{x} \mathrm{g}$ for $5 \mathrm{~min}$ at $37^{\circ} \mathrm{C}$. The apoptosis assay was performed using Annexin V-FITC. The cells $\left(5 \times 10^{5}\right.$ cells/well) were washed twice using washing buffer, and the suspension was cultured with the Annexin V-FITC and propidium iodide apoptosis kit [cat. no. 70-AP101-60; MultiSciences (Lianke) Biotech Co., Ltd.] in the dark at $25^{\circ} \mathrm{C}$ for 20 min according to the manufacturer's instructions. Binding buffer was subsequently added to each well. A flow cytometer was used to detect samples within $1 \mathrm{~h}$ and BD CellQuest ${ }^{\mathrm{TM}}$ Pro Software version 1.2 was used for analysis (BD Biosciences).

Reverse transcription-quantitative PCR (RT-qPCR). Total RNA in cultured cells or cells treated with drugs or plasmids was extracted with TRIzol regent (Invitrogen; Thermo Fisher Scientific, Inc.), according to the manufacturer's protocol. The Superscript II first-strand cDNA synthesis System (Invitrogen; Thermo Fisher Scientific, Inc.) was used to perform RT. RT-qPCR was carried out using the SYBR Fast qPCR Mix (Invitrogen; Thermo Fisher Scientific, Inc.) for HMGA2, X-linked inhibitor of apoptosis (XIAP), Bcl-2 and Bax. GAPDH was used as an internal control. The thermocycling conditions of qPCR were as follows: For HMGA2 and 
GAPDH, $95^{\circ} \mathrm{C}$ for $3 \mathrm{~min}, 95^{\circ} \mathrm{C}$ for $1 \mathrm{~min}$ followed by 30 cycles of $60^{\circ} \mathrm{C}$ for $30 \mathrm{sec}$ and $72^{\circ} \mathrm{C}$ for $30 \mathrm{sec}$; for XIAP, $95^{\circ} \mathrm{C}$ for $3 \mathrm{~min}, 95^{\circ} \mathrm{C}$ for $30 \mathrm{sec}$ followed by 35 cycles of $58^{\circ} \mathrm{C}$ for $30 \mathrm{sec}$ and $72^{\circ} \mathrm{C}$ for $30 \mathrm{sec}$; and for Bcl-2 and Bax, $95^{\circ} \mathrm{C}$ for $5 \mathrm{~min}$, $95^{\circ} \mathrm{C}$ for $10 \mathrm{sec}$ followed by 40 cycles of $60^{\circ} \mathrm{C}$ for $34 \mathrm{sec}$. Primers were purchased commercially (Invitrogen; Thermo Fisher Scientific, Inc.) and the sequences are listed in Table I. The expression levels of the above genes were determined using the $2^{-\Delta \Delta \mathrm{Cq}}$ method (26).

Western blot analysis. RIPA lysis buffer (Thermo Fisher Scientific, Inc.) was used to extract total protein from the cultured cells. Subsequently, protein concentration was determined using an Enhanced BCA Protein Assay kit (Beyotime Institute of Biotechnology). The proteins (20 $\mu \mathrm{g} / \mathrm{lane})$ were subjected to $12 \%$ SDS-PAGE and transferred to polyvinylidene fluoride (PVDF) membranes (EMD Millipore). Then 5\% milk PBS with $0.1 \%$ Triton X-100 was applied to block the membranes at room temperature for $2 \mathrm{~h}$, which were then incubated with the following: Anti-HMGA2 antibody (cat. no. ab97276; 1:2,000; Abcam), anti-XIAP antibody (cat. no. ab21278; 1:1,000; Abcam), anti-Bcl-2 antibody (cat. no. ab32124; 1:1,000; Abcam), anti-cleaved caspase-3 antibody (cat. no. ab2302; 1:1,000; Abcam), anti-Wnt antibody (cat. no. ab28472; 1:1,000; Abcam), anti-non-phospho (Np)- $\beta$-catenin antibody (cat. no. 8814; 1:1,000; Cell Signaling Technology, Inc.) and anti-GAPDH antibody (cat. no. ab9485; 1:2,500; Abcam) overnight at $4^{\circ} \mathrm{C}$. The membranes were then incubated with the appropriate horseradish peroxidaseconjugated secondary antibody (1:2,000; cat. no. SA00001-2; ProteinTech Group, Inc.) at $4^{\circ} \mathrm{C}$ for $1 \mathrm{~h}$ after washing with PBST (containing 0.05\% Tween-20) three times. Protein bands were detected with ECL (Thermo Fisher Scientific, Inc.) and visualized using Quantity One software version 4.6.2 (Bio-Rad Laboratories, Inc.).

Statistical analysis. Statistical analysis was detected by GraphPad Prism version 6.0 software (GraphPad Software, Inc.). All data were presented as the mean \pm standard deviation from three independent experiments. Differences were analyzed using one-way analysis of variance following Tukey's post hoc test for multiple comparisons. $\mathrm{P}<0.05$ was considered to indicate a statistically significant difference.

\section{Results}

Expression and transfection efficiency of HMGA2 in AML cells. The 7 AML cell lines, including NB4, HL60, KG1, U937, Kasumi-1, THP-1 and K562, were analyzed to determine the expression of HMGA2. As shown in Fig. 1A, the HL60, KG1, U937, Kasumi-1, THP-1 and K562 cell lines had higher expressions of HMGA2 than NB4 cells. Therefore, NB4, which had a relatively low expression of HMGA2, was selected for the HMGA2 overexpression experiments, and HL60 was selected for the siHMGA2 transfection experiments. RT-qPCR (Fig. 1B) and western blot analysis (Fig. 1C and $\mathrm{D})$ revealed a decreased expression of HMGA2 $(\mathrm{P}<0.01)$ in siHMGA2 HL60 cells and an elevated expression of HMGA2 $(\mathrm{P}<0.01)$ in NB4 cells, thereby indicating successful transfection.
Table I. Primers used in reverse transcription-quantitative PCR.

\begin{tabular}{lll}
\hline Gene & Primer & \multicolumn{1}{c}{ Sequence (5'-3') } \\
\hline HMGA2 & Forward & AGTCCCTCTAAAGCAGCTCAAAAG \\
& Reverse & GCCATTTCCTAGGTCTGCCTC \\
XIAP & Forward & ATGACTTTTAACAGTTTTGAAGG \\
& Reverse & GCTCGTGCCAGTGTTGATGCTG \\
Bcl-2 & Forward & GGATTGTGGCCTTCTTTGAG \\
& Reverse & TACCCAGCCTCCGTTATCCT \\
Bax & Forward & CCGATTCATCTACCCTGCTG \\
& Reverse & TGAGCAATTCCAGAGGCAGT \\
GAPDH & Forward & AGCCACATCGCTCAGACAC \\
& Reverse & GCCCAATACGACCAAATCC \\
\hline
\end{tabular}

HMGA2, high-mobility group AT-hook 2; XIAP, X-linked inhibitor of apoptosis.

HMGA2 regulates the proliferation, apoptosis, migration and invasion of AML HL60 and NB4 cells. As aforementioned, the present study selected two AML cell lines, which either possessed a high or low expression of HMGA2, and were subsequently transfected with either silencing or overexpression HMGA2 plasmids. The results revealed that silencing HMGA2 decreased HL60 cell viability in 24 h; however, no significant difference in comparison to control was identified. However, siHMGA2 significantly inhibited cell proliferation from $48 \mathrm{~h}$, compared with the control $(\mathrm{P}<0.01$; Fig. $2 \mathrm{~A})$. In addition, in NB4 cell, overexpressing HMGA2 promoted cell viability starting from $48 \mathrm{~h}(\mathrm{P}<0.05$; Fig. $2 \mathrm{~B})$. In regard to cell apoptosis, the Annexin-V-FITC assay revealed that silencing HMGA2 significantly induced cell apoptosis $(\mathrm{P}<0.01)$ and overexpression of HMGA2 produced the opposite result $(\mathrm{P}<0.05$; Fig. 2C and $\mathrm{D})$. These results were in agreement with the expression levels of the apoptosis-related genes in AML cells. Silencing HMGA2 significantly suppressed the mRNA and protein expressions of XIAP $(\mathrm{P}<0.01)$ and Bcl-2 $(\mathrm{P}<0.01)$, and significantly increased Bax and cleaved caspase- 3 the mRNA and protein levels $(\mathrm{P}<0.01$; Fig. 2E-G). In addition, significantly increased expression levels of XIAP and Bcl-2, and significantly reduced expression levels of Bax and cleaved caspase-3 were found in the NB4 cells overexpressing HMGA2 ( $\mathrm{P}<0.01$; Fig. 2E-G). Subsequently, the effect of HMGA2 on cell migration (Fig. 3A) and invasion (Fig. 3B) was investigated. As excepted, silencing HMGA2 significantly inhibited cell migration $(\mathrm{P}<0.01$; Fig. $3 \mathrm{C})$ and invasion $(\mathrm{P}<0.01$; Fig. 3D). By contrast, overexpression of HMGA 2 contributed to the promotion of cell migration and invasion $(\mathrm{P}<0.01)$.

Effect of HMGA2 on cell sensitivity to DNR in AML HL60 and NB4 cells. DNR in combination with Cytarabine is widely accepted as a classical AML induction mitigation scheme (27). In addition, Idarubicin has been approved by the US Food and Drug Administration for the combination chemotherapy for AML since 1990 (28). DNR has a certain inhibitory effect on AML, which was confirmed in the present study as presented 


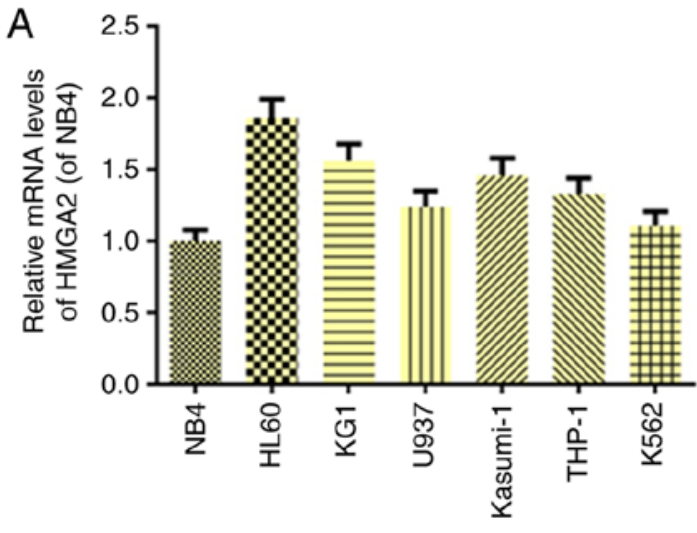

AML cell lines

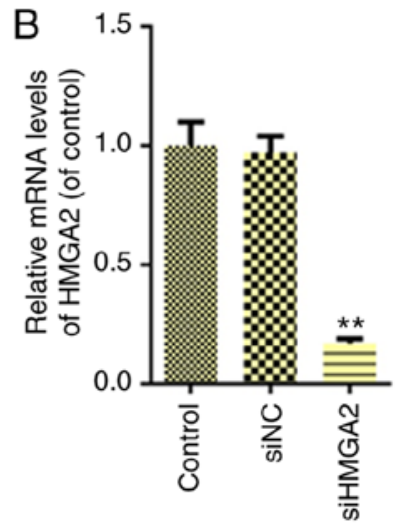

Silencing groups

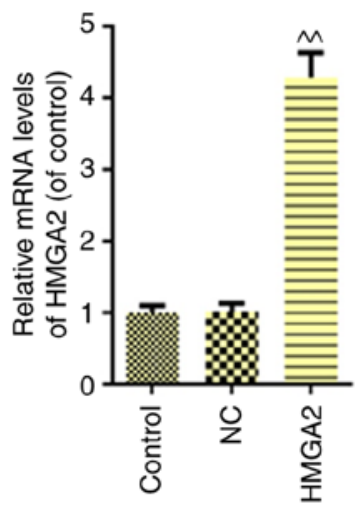

Over-expressing groups

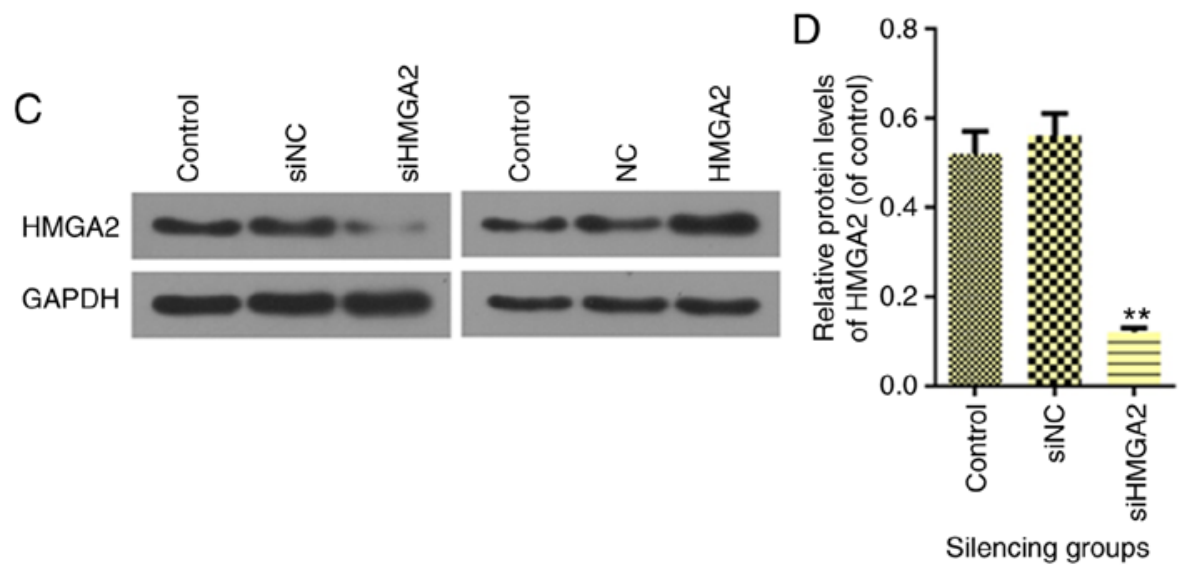

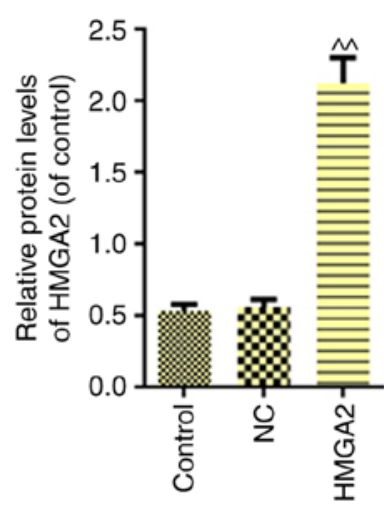

Over-expressing groups

Figure 1. Expression and transfection efficiency of HMGA2 in acute myelocytic leukemia cells. (A) Seven acute myelocytic leukemia cell lines (NB4, HL60, KG1, U937, Kasumi-1, THP-1 and K562) were used to determine the mRNA expression of HMGA2 via RT-qPCR. siHMGA2 was successfully transfected into HL60 cells and plasmids overexpressing HMGA2 were successfully transfected into NB4 cells. The transfection efficiency of HMGA2 in HL60 (left panel) and NB4 (right panel) cells was determined via (B) RT-qPCR and (C and D) western blot analysis. GAPDH was used as the internal control. Data were presented as the mean \pm standard deviation from three independent experiments. ${ }^{* *} \mathrm{P}<0.01 \mathrm{vs}$. HL60 cell control; ${ }^{\wedge} \mathrm{P}<0.01 \mathrm{vs}$. NB4 cell control. HMGA2, high-mobility group AT-hook 2 overexpression group; RT-qPCR, reverse transcription-quantitative PCR; si-, small interfering RNA; NC, negative control.

in Fig. 4A $(\mathrm{P}<0.01)$. In addition, silencing HMGA2 contributed to the inhibitory effect on cell viability induced by DNR (P<0.05; Fig. 4A). Nevertheless, overexpression of HMGA2 could significantly reverse the DNR-induced reduction of cell proliferation $(\mathrm{P}<0.01$; Fig. $4 \mathrm{~A})$. Furthermore, the results demonstrated that the mRNA and protein levels of HMGA2 were not altered when comparing the NC and NC + DNR groups, indicating that DNR did not affect HMGA2 expression $(\mathrm{P}>0.05)$. Compared with siNC + DNR, siHMGA2 in combination with DNR significantly downregulated the expression of HMGA2 both at the mRNA and protein levels $(\mathrm{P}<0.01$; Fig. 4B-D). However, in NB4 cells, the effect of DNR or HMGA2 overexpression + DNR on the expression of HMGA2 was opposite to that observed in HL60 cell $(\mathrm{P}<0.01$; Fig. 4B-D).

HMGA2 affects the DNR-induced inhibitory effect of Wnt/ $\beta$-catenin signaling in AML HL6O and NB4 cells. An increasing body of evidence has indicated that abnormal activation of $\mathrm{Wnt} / \beta$-catenin signaling contributes to the progression of tumors (29-31). Therefore, the present study investigated whether HMGA2 regulated this signaling pathway. Western blot analysis revealed that DNR could inhibit the protein expressions of Wnt and Np- $\beta$-catenin $(\mathrm{P}<0.05$; Fig. 4E-G), but its inhibitory effect was not more significant than siHMGA2 treatment $(\mathrm{P}<0.01)$. Notably, when siHMGA2 was combined with DNR, the Wnt and $\mathrm{Np}-\beta$-catenin protein levels were significantly reduced $(\mathrm{P}<0.01)$, indicating that AML cells treated with this combination had suppressed Wnt/ $\beta$-catenin signaling. On the other hand, overexpression of HMGA2 not only increased the protein expressions of Wnt $(\mathrm{P}<0.01)$ and $\mathrm{Np}-\beta$-catenin $(\mathrm{P}<0.05)$, but also attenuated the inhibitory effects of DNR on the Wnt and Np- $\beta$-catenin levels ( $\mathrm{P}<0.05$; Fig. $4 \mathrm{E}$ and $\mathrm{G})$. For the experiments involving the agonist and antagonist of Wnt/ $\beta$-catenin signaling, $\mathrm{LiCl}$ and XAV939 were employed, respectively. As expected, the agonist $\mathrm{LiCl}$ significantly promoted the expressions of Wnt and $\mathrm{Np}-\beta$-catenin $(\mathrm{P}<0.01$; Fig. 5A and $\mathrm{B}$ ), and the antagonist XAV939 significantly inhibited $\mathrm{Wnt} / \beta$-catenin signaling activation $(\mathrm{P}<0.01 ;$ Fig. $5 \mathrm{C}$ and D). The results further revealed that DNR partially suppressed the promotional effects of $\mathrm{LiCl}$ on the expressions of Wnt and Np- $\beta$-catenin $(\mathrm{P}<0.01$; Fig. $5 \mathrm{~A}$ and $\mathrm{B})$. In addition, siHMGA2 could further enhance the inhibitory effect 

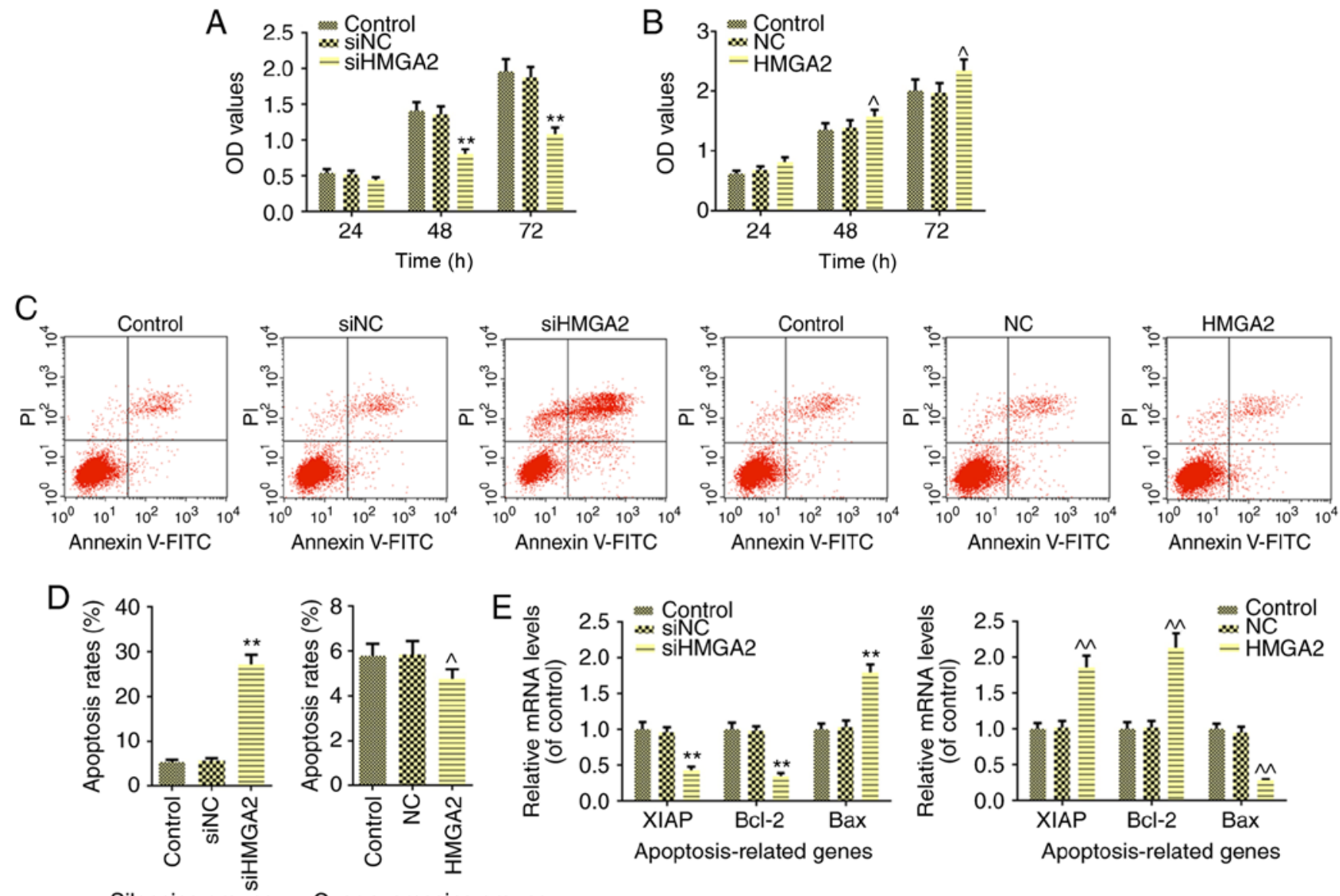

Silencing groups Over-expressing groups
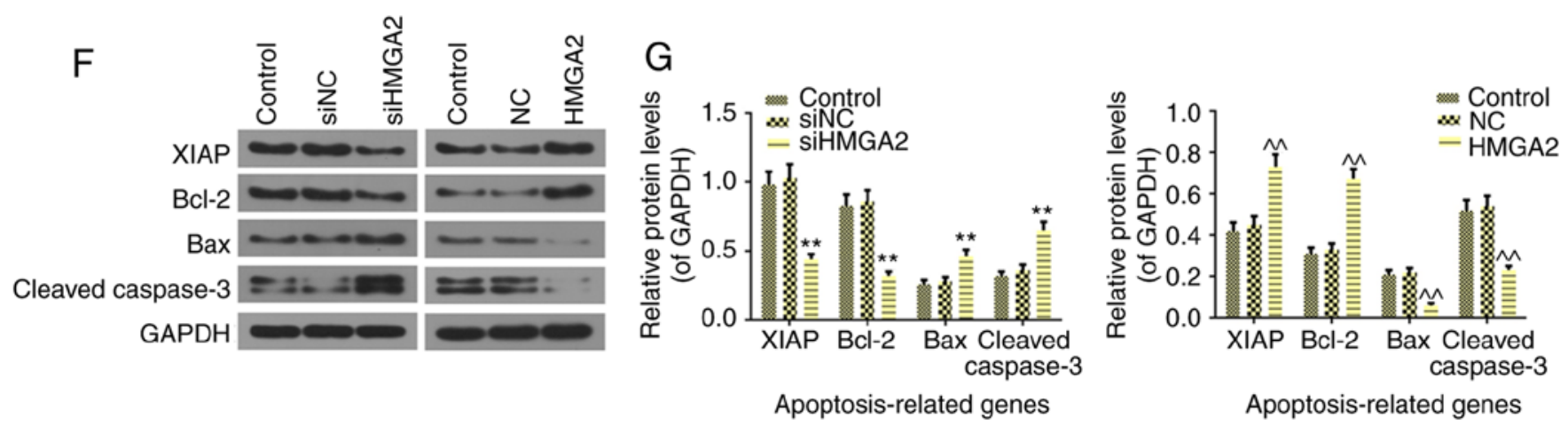

Figure 2. HMGA2 regulates the proliferation and apoptosis of acute myelocytic leukemia HL60 and NB4 cells. (A) The effect of silencing HMGA2 on cell viability was evaluated by MTT assay in HL60 cells at 24, 48 and $72 \mathrm{~h}$. (B) The effect of overexpressing HMGA2 on cell viability was determined by MTT assay in NB4 cells at 24, 48 and $72 \mathrm{~h}$. (C and D) The effect of HMGA2 on cell apoptosis was determined by flow cytometry in HL60 and NB4 cell. (E) The effects of HMGA2 on the mRNA expressions of XIAP, Bcl-2 and Bax were determined by reverse transcription-quantitative PCR in HL60 and NB4 cells. (F and G) The effects of HMGA2 on the protein expressions of XIAP, Bcl-2, Bax and cleaved caspase-3 were determined by western blotting in HL60 and NB4 cells. GAPDH was used as an internal control. Data were presented as the mean \pm standard deviation from three independent experiments. ${ }^{* *} \mathrm{P}<0.05$ vs. HL60 cell control; ${ }^{\wedge} \mathrm{P}<0.05$ and ${ }^{\wedge} \mathrm{P}<0.01$ vs. NB4 cell control. HMGA2, high-mobility group AT-hook 2 overexpression group; si-, small interfering RNA; $\mathrm{NC}$, negative control; XIAP, X-linked inhibitor of apoptosis.

of DNR, which was partially reversed by $\mathrm{LiCl}$ (Wnt, $\mathrm{P}<0.05$; Np- $\beta$-catenin, $\mathrm{P}<0.01)$. As shown in Fig. $5 \mathrm{C}$ and $\mathrm{D}$, XAV939 in combination with DNR had the strongest inhibitory effect on Wnt and Np- $\beta$-catenin expressions, when compared with treatment alone $(\mathrm{P}<0.01)$. Overexpression of HMGA2 could significantly upregulate the Wnt and $\mathrm{Np}-\beta$-catenin protein levels in DNR treated cells, compared with DNR only treatment $(\mathrm{P}<0.05)$ and the effect of HMGA2 overexpression in turn was partially reversed by the combination of XAV939 and DNR ( $\mathrm{P}<0.01$; Fig. 5C and D). In addition, $\mathrm{LiCl}$ could induce cell proliferation $(\mathrm{P}<0.05$; Fig. $5 \mathrm{E})$ as expected and XAV939 significantly inhibited cell viability $(\mathrm{P}<0.01$; Fig. 5F). DNR could also significantly reverse the changes in the cell viability of the cells treated with $\mathrm{LiCl}(\mathrm{P}<0.01)$ or XAV939 $(\mathrm{P}<0.05)$. Furthermore, silencing HMGA2 suppressed the increase in cell viability in DNR-treated HL60 cells, which was partially reversed by $\mathrm{LiCl}(\mathrm{P}<0.05)$. Similarly, overexpressing HMGA2 increased cell viability in DNR-induced NB4 cells, and this effect was partially reversed by XAV939 treatment $(\mathrm{P}<0.01)$. 

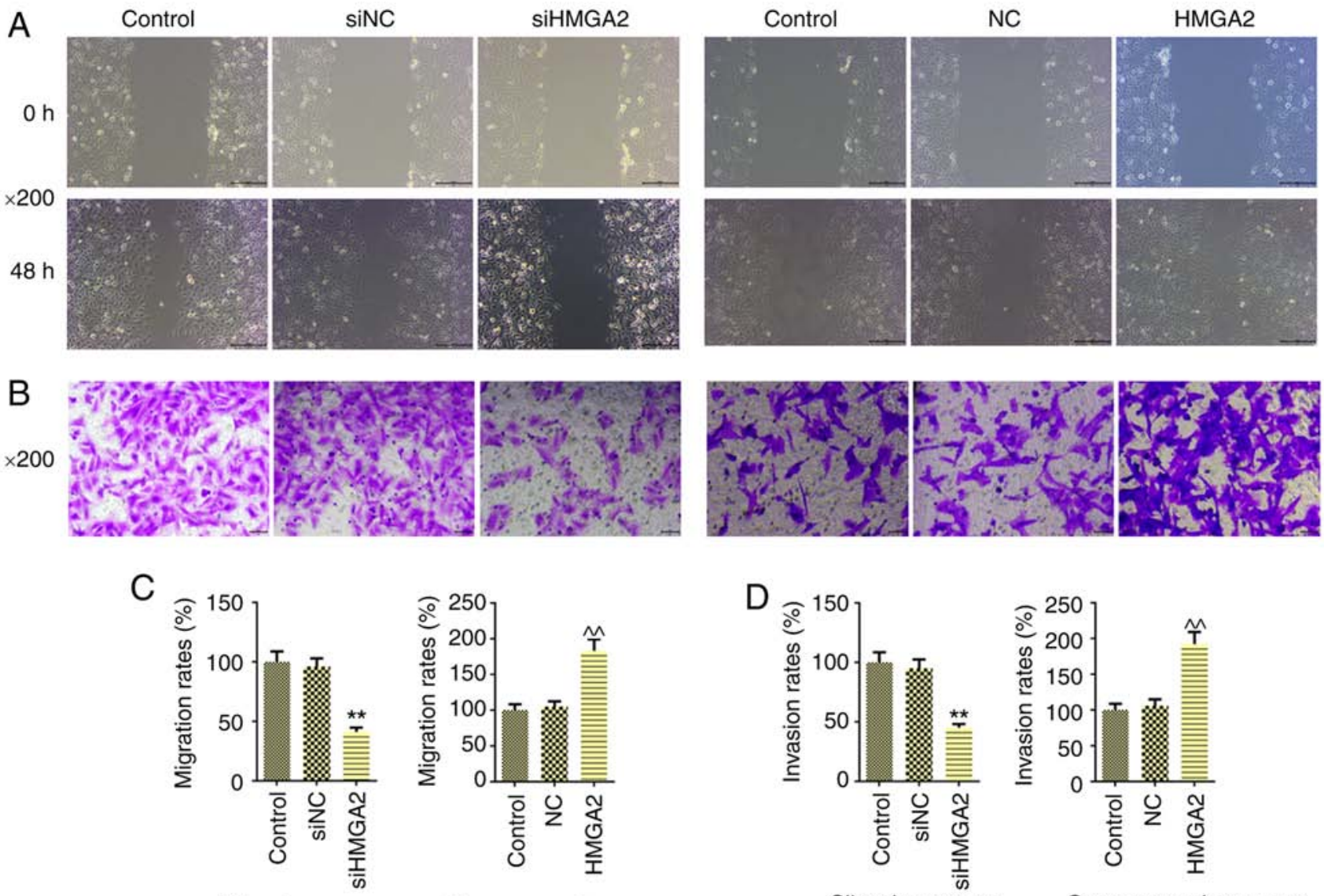

Silencing groups

Over-expressing groups

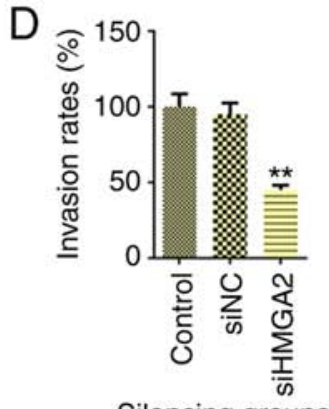

Silencing groups

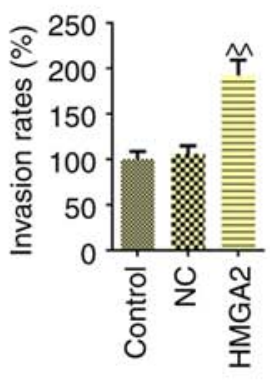

Over-expressing groups

Figure 3. HMGA2 regulates the migration and invasion of AML HL60 and NB4 cells. (A) Cell migration was detected by wound scratch assay and observed at 0 and $48 \mathrm{~h}$ using an optical microscope (magnification, x200). (B) Cell invasion was evaluated via a Transwell assay and observed after $48 \mathrm{~h}$ using an optical microscope (magnification, x200). (C) The effect of HMGA2 on AML cell migration in HL60 and NB4 cells. (D) The effect of HMGA2 on AML cell invasion in HL60 and NB4 cells. Data were presented as the mean \pm standard deviation from three independent experiments. ${ }^{* *} \mathrm{P}<0.05 \mathrm{vs.} \mathrm{HL60} \mathrm{cell} \mathrm{control;}$ ${ }^{\wedge} \mathrm{P}<0.01$ vs. NB4 cell control. AML, acute myelocytic leukemia; HMGA2, high-mobility group AT-hook 2 overexpression group; si-, small interfering RNA; $\mathrm{NC}$, negative control.

\section{Discussion}

The present study investigated the HMGA2 levels in several AML cell lines, amongst which the NB4 cell line had relatively reduced expression of HMGA2, and HL60 cells had the greatest expression of HMGA2. Subsequently, these two cell lines were selected to be used in the following experiments. To the best of our knowledge, previous studies have only reported that HMGA2 has a high expression in a large number of malignant tumors including thyroid, ovarian, prostate, gallbladder and bladder cancers, and gastric adenocarcinoma and esophageal squamous cell carcinoma (32-35). In addition, it has been reported that elevated HMGA2 levels were detected in AML (36-39) and Nyquist et al (39) demonstrated that $\mathrm{t}(12 ; 13)(\mathrm{q} 14 ; \mathrm{q} 31)$ led to HMGA2 upregulation in AML. Through transfection with siHMGA2 in HL60 cells and overexpression HMGA2 in NB4 cells, the present study revealed that silencing HMGA2 could inhibit cell proliferation, migration and invasion as well as induce cell apoptosis. The present in vitro experiments were in agreement with the results obtained by Tan et al (38) who reported that reduced expression of HMGA2 in AML cells also suppressed cell proliferation. In addition, a marked reduction in XIAP and Bcl-2 expression levels and upregulation of Bax and cleaved caspase-3 levels occurred in following siHMGA2 transfection in HL60 cells. It has been well established that XIAP is the most potent endogenous caspase inhibitor in the IAP family, which is the only endogenous protein capable of acting on both the initiation and effect of caspases $(40,41)$. If XIAP is activated, the junction region of its baculoviral IAP repeat 1 (BIR1) and BIR2 domains can bind to the active sites of the effectual caspase-3,7 to competitively inhibit the activity of caspase-3,7 (42). Saraei et al (43) also suggested that XIAP could be putative in resensitizing tumor necrosis factor-related apoptosis-inducing ligand in leukemia.

The present study is, to the best of our knowledge, not the first to determine the levels of HMGA2 in AML cells, but is the first to study the effect of it on DNR in regard to AML cell sensitivity. DNR, as an anthracycline-based chemotherapy drug, is also a cycle nonspecific agent with strong anti-tumor properties. Currently, almost all first-line standard regimens contain DNR (44). Quiney et al (45) reported that there were some patients with DNR resistance in the clinic. The present results revealed that silencing HMGA2 could enhance the inhibition of AML cells by DNR $(10 \mu \mathrm{g} / \mathrm{ml})$, while overexpressing HMGA2 presented the opposite result in comparison with that produced by silencing HMGA2. Previous studies have demonstrated that targeting HMGA2 could regulate 


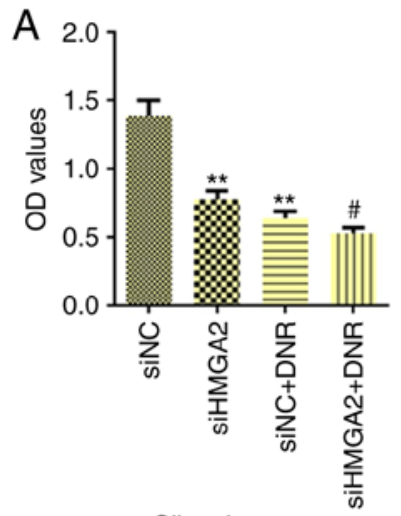

Silencing groups

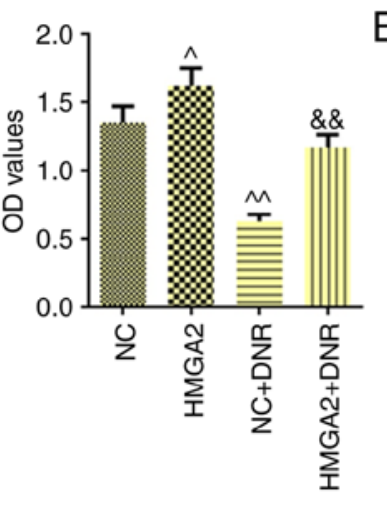

Over-expressing groups

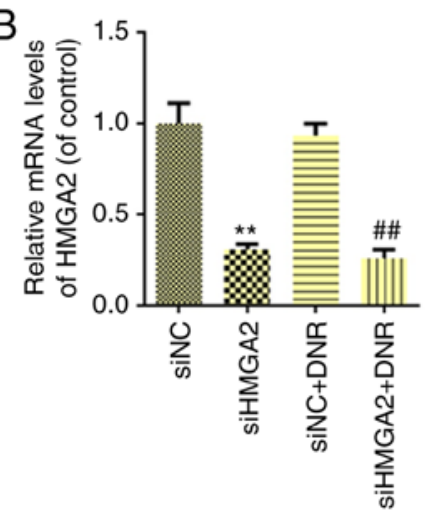

Silencing groups

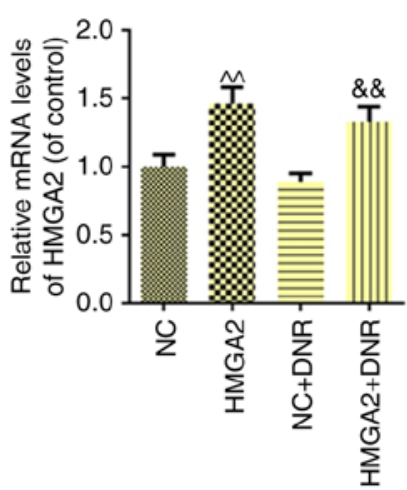

Over-expressing groups

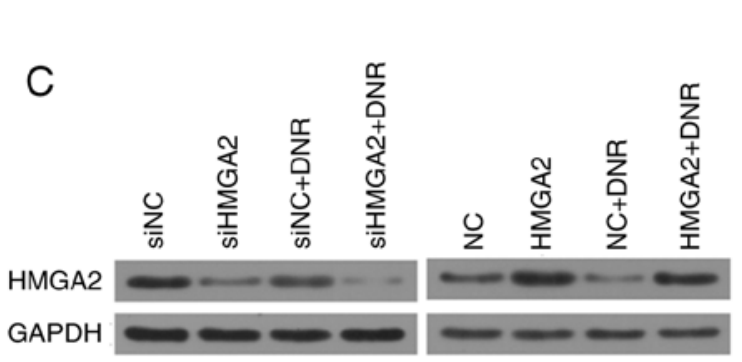

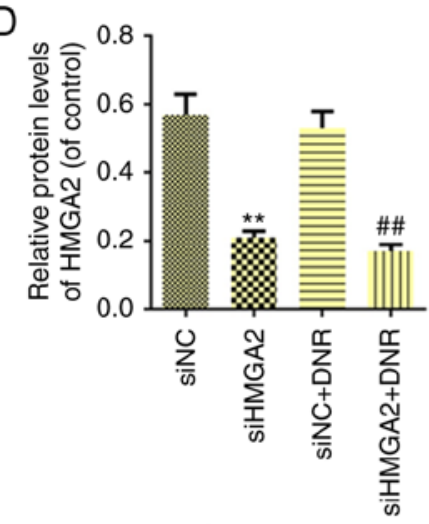

Silencing groups

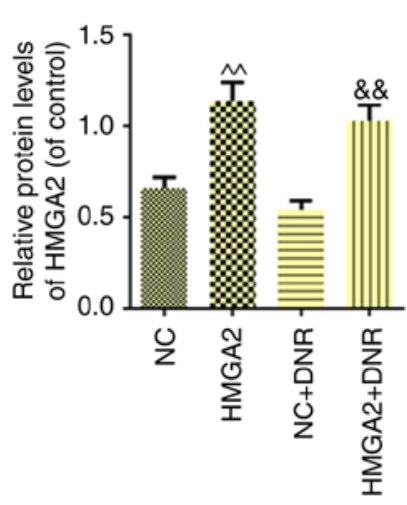

Over-expressing groups
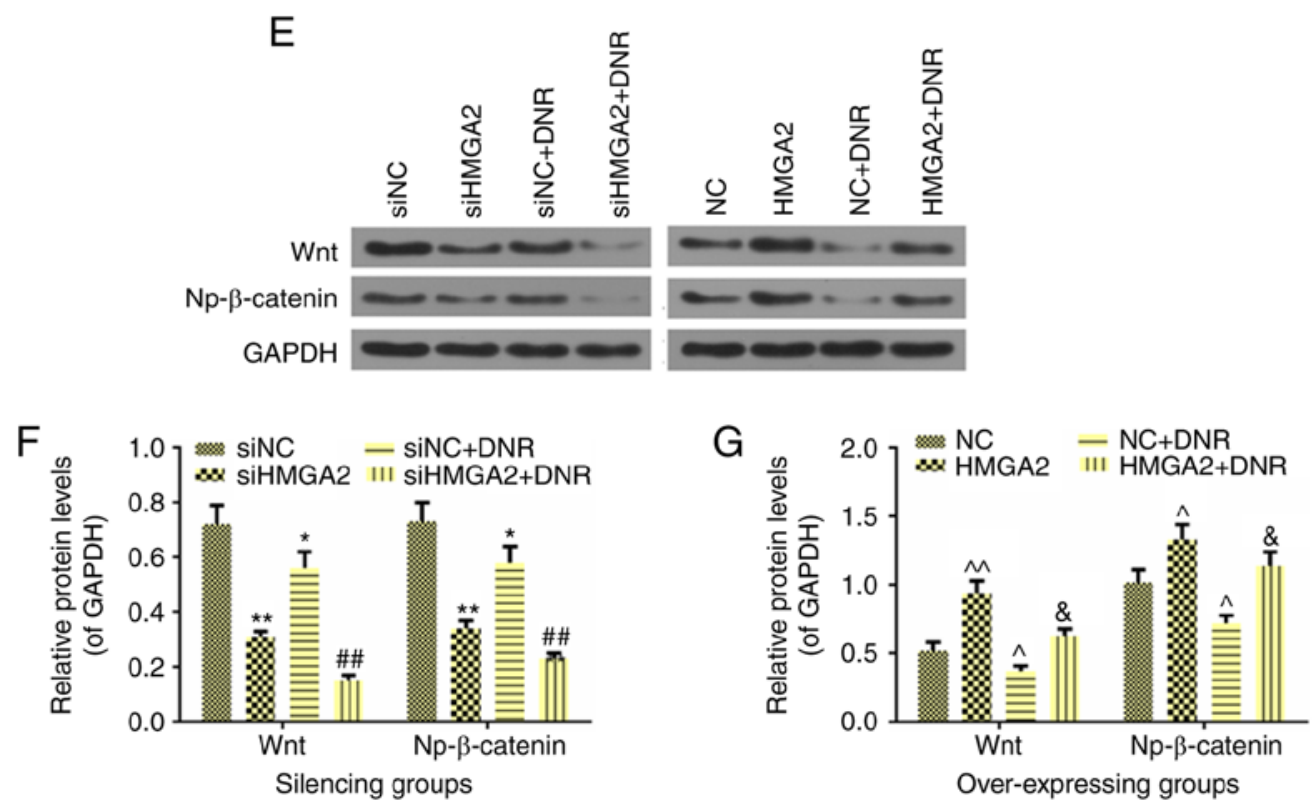

Figure 4. Effects of HMGA2 on cell sensitivity to DNR and the expressions of Wnt and Np- $\beta$-catenin in AML HL60 and NB4 cells. (A) The effect of HMGA2 on cell sensitivity to DNR as determined by MTT assay. (B) The mRNA level of HMGA2 was detected by reverse transcription-quantitative PCR to observe the effect of silencing or overexpressing HMGA2 on DNR in AML HL60 and NB4 cells. (C and D) The protein level of HMGA2 was detected by western blotting to observe the effect of silencing or overexpressing HMGA2 on DNR in AML HL60 and NB4 cells. (E) The effects of HMGA2 on the expressions of Wnt and Np- $\beta$-catenin, which were inhibited by DNR, were detected by western blot analysis in AML HL60 and NB4 cells. (F) Relative protein levels of Wnt and Np- $\beta$-catenin, which were regulated by silencing HMGA2 in HL60 cell. (G) Relative protein levels of Wnt and Np- $\beta$-catenin, which were regulated by overexpressing HMGA2 in NB4 cell. GAPDH was used as an internal control. Data were presented as the mean \pm standard deviation from three independent experiments. ${ }^{*} \mathrm{P}<0.05$ and ${ }^{* *} \mathrm{P}<0.01$ vs. of HL60 cell siNC; ${ }^{\wedge} \mathrm{P}<0.05$ and ${ }^{\wedge \wedge} \mathrm{P}<0.01$ vs. NB4 cell NC; ${ }^{\#} \mathrm{P}<0.05$ and ${ }^{\# \#} \mathrm{P}<0.01$ vs. siNC+DNR; ${ }^{\text {\& }} \mathrm{P}<0.05$ and ${ }^{\& \&} \mathrm{P}<0.01$ vs. NC+DNR. DNR, daunorubicin; AML, acute myelocytic leukemia; HMGA2, high-mobility group AT-hook 2 overexpression group; si-, small interfering RNA; NC, negative control; Np- $\beta$-catenin, non-phospho- $\beta$-catenin.

chemoresistance in several types of cancers, such as colorectal cancer in which HMGA2 could increase the chemoresistance to 5-fluorouracil by activating disheveled segment polarity protein 2/Wnt signaling (46). 

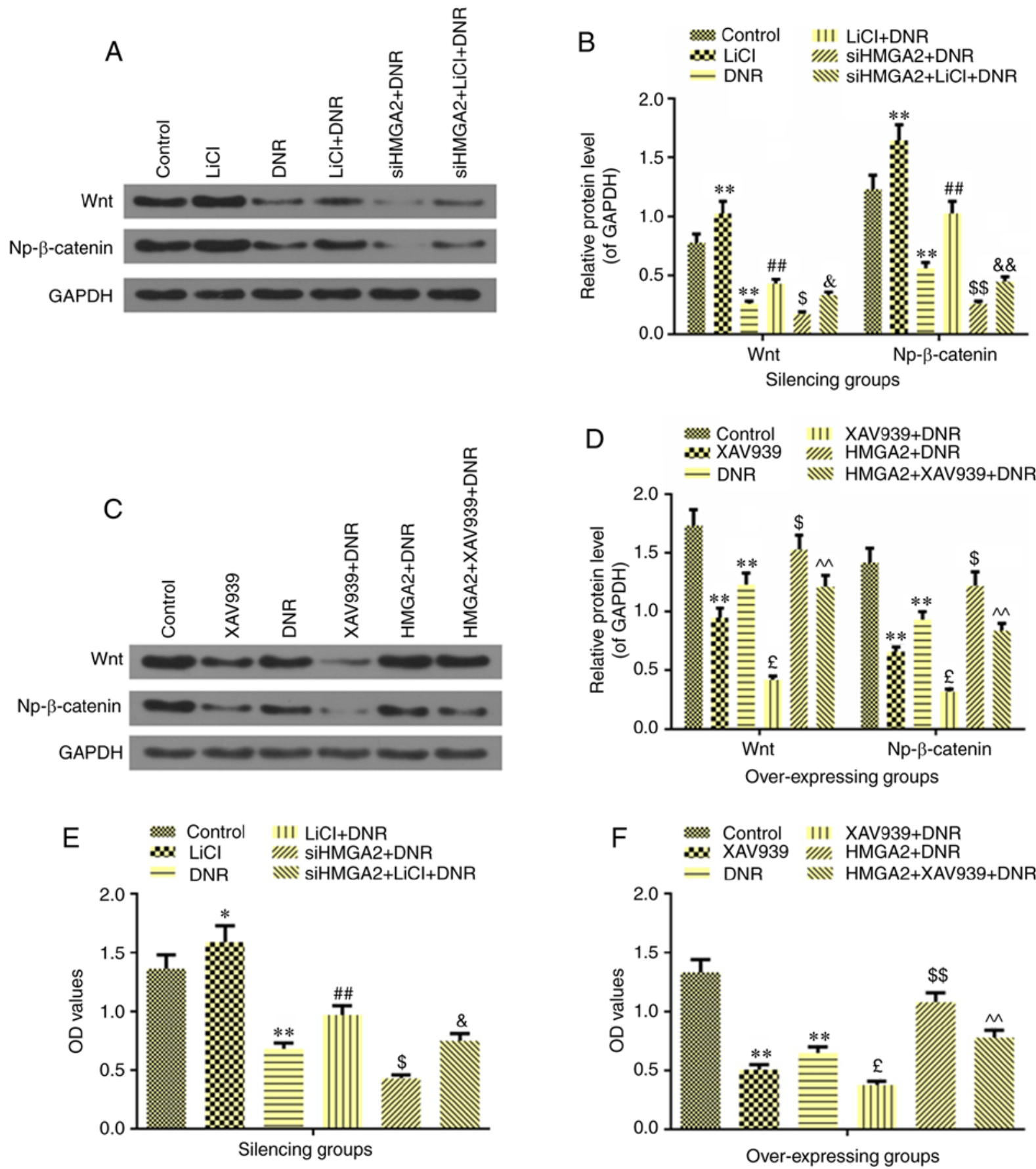

Figure 5. Effects of HMGA2 on the Wnt/ß-catenin signaling pathway and cell viability following treatment with LiCl, XAV939 or DNR in AML HL60 and NB4 cells. (A) The effects of silencing HMGA2 on the protein expressions of Wnt and Np- $\beta$-catenin in AML HL60 cells treated with LiCl or DNR were determined by western blot analysis. (B) Relative protein levels in AML HL60 cells after silencing HMGA2. (C) The effects of overexpressing HMGA2 on the protein expressions of Wnt and Np- $\beta$-catenin in AML NB4 cells treated with XAV939 or DNR were determined by western blot analysis. (D) Relative protein levels in AML NB4 cells after HMGA2 overexpression. (E) The effects of silencing HMGA2 on the cell viability in AML HL60 cells treated with LiCl or DNR as determined by MTT assay. (F) The effects of overexpressing HMGA2 on the cell viability in AML NB4 cells treated with XAV9393 or DNR were evaluated by MTT assay. GAPDH was used as an internal control. Data were presented as the mean \pm standard deviation from three independent experiments. ${ }^{*} \mathrm{P}<0.05$ and ${ }^{* *} \mathrm{P}<0.01$ vs. Control; ${ }^{\# \#} \mathrm{P}<0.01$ vs. $\mathrm{LiCl} ;{ }^{\mathrm{S}} \mathrm{P}<0.05$ and ${ }^{\$ \$} \mathrm{P}<0.01$ vs. DNR; ${ }^{\&} \mathrm{P}<0.05$ and ${ }^{\& \&} \mathrm{P}<0.01$ vs. LiCl+DNR; ${ }^{\mathrm{f}} \mathrm{P}<0.05$ vs. $\mathrm{XAV} 939 ;{ }^{\wedge} \mathrm{P}<0.01$ vs. XAV939+DNR. DNR, daunorubicin; AML, acute myelocytic leukemia; HMGA2, high-mobility group AT-hook 2 overexpression group; si-, small interfering RNA; NC, negative control; Np- $\beta$-catenin, non-phospho- $\beta$-catenin.

The molecular mechanism of the role of HMGA2 in the genesis and development of AML is not clearly defined. A previous study has suggested that HMGA2 could promote the growth of AML cells by regulating the Akt signaling (38). Tan et al (47) subsequently demonstrated that silencing HMGA2 induced the terminal differentiation of myeloid leukemia primary blasts and cell lines. Ohshima et al (48) suggested that HMGA2 and the let-7 family were negatively regulated and were correlated with the invasiveness of gastric cancer. This negative regulatory effects contributed to tumorigenesis via the regulation of some molecular signaling pathways such as the growth factor signaling 
pathway and Ras signaling pathway (48). Watanabe et al (49) believed that the upregulation of HMGA2 expression activated the Ras signaling pathway, leading to the development of pancreatic cancer. The Wnt signaling pathway not only played a key role in regulating embryonic development, but also its abnormal activation was closely associated with the progression of tumors (50-53). Therefore, the present study ultimately indicated that the $\mathrm{Wnt} / \beta$-catenin pathway was the underlying mechanism. $\beta$-catenin cannot be degraded in the presence of Wnt signaling. Thus, a large number of free $\beta$-catenins accumulate in the cytoplasm and enter the nucleus in order to bind to the transcription factor $\mathrm{T}$ cytokine/lymphocyte enhancer, which initiates a series of downstream target molecules such as c-myc and cyclin D1 expression, thereby participating in cell proliferation and apoptosis (54). The present study revealed that silencing HMGA 2 markedly inhibited Wnt and $\mathrm{Np}$ - $\beta$-catenin (active) protein levels of Wnt signaling and enhanced protein sensitivities to DNR; moreover, the activity of the Wnt signaling agonist $\mathrm{LiCl}$ was partially reversed in a previous study (55). To the best of our knowledge, the present study is the first to investigate the effect of HMGA2 on the regulation of $\mathrm{Wnt} / \beta$-catenin in AML cells. However, in gastric cancer, Zha et al (56) had already confirmed that HMGA2 was conducive to EMT by activating $\mathrm{Wnt} / \beta$-catenin signaling. Similarly, Wend et al (57) suggested that the Wnt10B/ $\beta$-catenin signaling was closely associated with HMGA2 and promoted metastatic triple-negative breast cancer cell proliferation.

In conclusion, the present study demonstrated that HMGA2 played important roles in driving AML progression in HL60 and NB4 cells, potentially through the activation of the Wnt/ $\beta$-catenin signaling pathway. In addition, it was revealed that HMGA2 could regulate AML cell sensitivity to DNR. As such HMGA 2 may be a promising molecular marker for AML diagnosis.

\section{Acknowledgements}

Not applicable.

\section{Funding}

No funding was received.

\section{Availability of data and materials}

The datasets used and/or analyzed during the current study are available from the corresponding author on reasonable request.

\section{Authors' contributions}

SY made substantial contributions to the conception and design of the study. YG, QH, GW, SC, MZ and YW acquired, analyzed and interpreted the data.SY and YG drafted the article and revised it critically for important intellectual content. All authors gave final approval of the version to be published. All authors agree to be held accountable for all aspects of the work in ensuring that questions related to the accuracy or integrity of the work are appropriately investigated and resolved.

\section{Ethics approval and consent to participate}

Not applicable.

\section{Patient consent for publication}

Not applicable.

\section{Competing interests}

The authors declare that they have no competing interests.

\section{References}

1. Miller KD, Siegel RL, Lin CC, Mariotto AB, Kramer JL, Rowland JH, Stein KD, Alteri R and Jemal A: Cancer treatment and survivorship statistics, 2016. CA Cancer J Clin 66: 271-289, 2016.

2. Döhner H, Weisdorf DJ and Bloomfield CD: Acute myeloid leukemia. N Engl J Med 373: 1136-1152, 2015.

3. Lee SC and Abdel-Wahab O: Therapeutic targeting of splicing in cancer. Nat Med 22: 976-986, 2016.

4. Buchner M and Müschen M: Targeting the B-cell receptor signaling pathway in B lymphoid malignancies. Curr Opin Hematol 21: 341-349, 2014.

5. Piemontese S, Ciceri F, Labopin M, Bacigalupo A, Huang H, Santarone S, Gorin NC, Koc Y, Wu D, Beelen D, et al: A survey on unmanipulated haploidentical hematopoietic stem cell transplantation in adults with acute leukemia. Leukemia 29: 1069-1075, 2015

6. Herbaux C, Genet P, Bouabdallah K, Pignon JM, Debarri H, Guidez S, Betrian S, Leleu X, Facon T, Morschhauser F, et al: Bendamustine is effective in T-cell prolymphocytic leukaemia. Br J Haematol 168: 916-919, 2015.

7. Döhner H, Estey EH, Amadori S, Appelbaum FR, Büchner T, Burnett AK, Dombret H, Fenaux P, Grimwade D, Larson RA, et al: Diagnosis and management of acute myeloid leukemia in adults: Recommendations from an international expert panel, on behalf of the European LeukemiaNet. Blood 115: 453-474, 2010.

8. Walter RB, Othus M, Burnett AK, Löwenberg B, Kantarjian HM, Ossenkoppele GJ, Hills RK, Ravandi F, Pabst T, Evans A, et al: Resistance prediction in AML: Analysis of 4601 patients from MRC/NCRI, HOVON/SAKK, SWOG and MD Anderson cancer center. Leukemia 29: 312-320, 2015.

9. Ramos NR, Mo CC, Karp JE and Hourigan CS: Current approaches in the treatment of relapsed and refractory acute myeloid leukemia. J Clin Med 4: 665-695, 2015.

10. Mrózek K, Heerema NA and Bloomfield CD: Cytogenetics in acute leukemia. Blood Rev 18: 115-136, 2004.

11. Rowley JD: Chromosomal translocations: Revisited yet again. Blood 112: 2183-2189, 2008.

12. Jin J, Yu M, Hu C, Ye L, Xie L, Jin J, Chen F and Tong H: Pesticide exposure as a risk factor for myelodysplastic syndromes: A meta-analysis based on 1,942 cases and 5,359 controls. PLoS One 9: e110850, 2014.

13. Wu J, Liu Z, Shao C, Gong Y, Hernando E, Lee P, Narita M, Muller W, Liu J and Wei JJ: HMGA2 overexpression-induced ovarian surface epithelial transformation is mediated through regulation of EMT genes. Cancer Res 71: 349-359, 2011.

14. Young AR and Narita M: Oncogenic HMGA2: Short or small? Genes Dev 21: 1005-1009, 2007.

15. Fedele M and Fusco A: HMGA and cancer. Biochim Biophys Acta 1799: 48-54, 2010.

16. Morishita A, Zaidi MR, Mitoro A, Sankarasharma D, Szabolcs M, Okada Y, D'Armiento J and Chada K: HMGA2 is a driver of tumor metastasis. Cancer Res 73: 4289-4299, 2013.

17. Natarajan S, Hombach-Klonisch S, Dröge P and Klonisch T: HMGA2 inhibits apoptosis through interaction with ATR-CHK1 signaling complex in human cancer cells. Neoplasia 15: 263-280, 2013.

18. Li O, Li J and Dröge P: DNA architectural factor and protooncogene HMGA2 regulates key developmental genes in pluripotent human embryonic stem cells. FEBS Lett 581: 3533-3537, 2007. 
19. Meyer B, Krisponeit D, Junghanss C, Murua Escobar H and Bullerdiek J: Quantitative expression analysis in peripheral blood of patients with chronic myeloid leukaemia: Correlation between HMGA2 expression and white blood cell count. Leuk Lymphoma 48: 2008-2013, 2007.

20. Wei J,Li H, Wang S, Li T, Fan J, Liang X, Li J, Han Q, Zhu L, Fan L and Zhao RC: let-7 enhances osteogenesis and bone formation while repressing adipogenesis of human stromal/mesenchymal stem cells by regulating HMGA2. Stem Cells Dev 23: 1452-1463, 2014.

21. Fusco A and Fedele M: Roles of HMGA proteins in cancer. Nat Rev Cancer 7: 899-910, 2007.

22. Ma S, Yang LL, Niu T, Cheng C, Zhong L, Zheng MW, Xiong Y Li LL, Xiang R, Chen LJ, et al: SKLB-677, an FLT3 and $\mathrm{Wnt} / \beta$-catenin signaling inhibitor, displays potent activity in models of FLT3-driven AML. Sci Rep 5: 15646, 2015.

23. Sokolowski KM, Koprowski S, Kunnimalaiyaan S Balamurugan M, Gamblin TC and Kunnimalaiyaan M: Potential molecular targeted therapeutics: Role of PI3-K/Akt/mTOR inhibition in cancer. Anticancer Agents Med Chem 16: 29-37, 2016.

24. Li J, Volk A, Zhang J, Cannova J, Dai S, Hao C, Hu C, Sun J, $\mathrm{Xu} \mathrm{Y}$, Wei W, et al: Sensitizing leukemia stem cells to NF- $\mathrm{BB}$ inhibitor treatment in vivo by inactivation of both TNF and IL-1 signaling. Oncotarget 8: 8420-8435, 2017.

25. Cook AM, Li L, Ho Y, Lin A, Li L, Stein A, Forman S, Perrotti D, Jove R and Bhatia R: Role of altered growth factor receptor-mediated JAK2 signaling in growth and maintenance of human acute myeloid leukemia stem cells. Blood 123: 2826-2837, 2014.

26. Livak KJ and Schmittgen TD: Analysis of relative gene expression data using real-time quantitative PCR and the 2(-Delta Delta C(T)) method. Methods 25: 402-408, 2001.

27. Lin TL and Levy MY: Acute myeloid leukemia: Focus on novel therapeutic strategies. Clin Med Insights Oncol 6: 205-217, 2012

28. Masaoka T, Ogawa M, Yamada K, Kimura K and Ohashi Y: A phase II comparative study of idarubicin plus cytarabine versus daunorubicin plus cytarabine in adult acute myeloid leukemia. Semin Hematol 33 (Suppl 3): S12-S17, 1996.

29. Shi S, Chen X, Liu H, Yu K, Bao Y, Chai J, Gao H and Zou L: LGR5 acts as a target of miR-340-5p in the suppression of cell progression and drug resistance in breast cancer via Wnt/ß-catenin pathway. Gene 683: 47-53, 2019.

30. Wang J, Mook RA Jr, Ren XR, Zhang Q, Jing G, Lu M, Spasojevic I, Lyerly HK, Hsu D and Chen W: Identification of DK419, a potent inhibitor of Wnt $/ \beta$-catenin signaling and colorectal cancer growth. Bioorg Med Chem 26: 5435-5442, 2018

31. Liu P, Chen B, Gu Y and Liu Q: PNMA1, regulated by miR-33a-5p, promotes proliferation and EMT in hepatocellular carcinoma by activating the $\mathrm{Wnt} / \beta$-catenin pathway. Biomed Pharmacother 108: 492-499, 2018.

32. Jin L, Lloyd RV, Henry MR, Erickson LA, Sebo TJ, Rumilla KM and Zhang J: The diagnostic utility of combination of HMGA2 and IMP3 qRT-PCR testing in thyroid neoplasms. Appl Immunohistochem Mol Morphol 23: 36-43, 2015.

33. Zhu C, Li J, Cheng G, Zhou H, Tao L, Cai H, Li P, Cao Q, Ju X, Meng X, et al: miR-154 inhibits EMT by targeting HMGA2 in prostate cancer cells. Mol Cell Biochem 379: 69-75, 2013.

34. Ding X, Wang Y, Ma X, Guo H, Yan X, Chi Q, Li J, Hou Y and Wang C: Expression of HMGA2 in bladder cancer and its association with epithelial-to-mesenchymal transition. Cell Prolif 47: $146-151,2014$.

35. Kong D, Su G, Zha L, Zhang H, Xiang J, Xu W, Tang Y and Wang Z: Coexpression of HMGA2 and Oct4 predicts an unfavorable prognosis in human gastric cancer. Med Oncol 31: 130, 2014

36. Pierantoni GM, Santulli B, Caliendo I,Pentimalli F, Chiappetta G, Zanesi N, Santoro M, Bulrich F and Fusco A: HMGA2 locus rearrangement in a case of acute lymphoblastic leukemia. Int J Oncol 23: 363-367, 2003.

37. Marquis M, Beaubois C, Lavallée VP, Abrahamowicz M Danieli C, Lemieux S, Ahmad I, Wei A, Ting SB, Fleming S, et al: High expression of HMGA2 independently predicts poor clinical outcomes in acute myeloid leukemia. Blood Cancer J 8: 68, 2018.

38. Tan L, Wei X,Zheng L, Zeng J, Liu H, Yang S and Tan H: Amplified HMGA2 promotes cell growth by regulating Akt pathway in AML. J Cancer Res Clin Oncol 142: 389-399, 2016.

39. Nyquist KB, Panagopoulos I, Thorsen J, Roberto R, Wik HS, Tierens A, Heim S and Micci F: t(12;13)(q14;q31) leading to HMGA2 upregulation in acute myeloid leukaemia. Br J Haematol 157: 769-771, 2012.
40. Fulda S and Vucic D: Targeting IAP proteins for therapeutic intervention in cancer. Nat Rev Drug Discov 11: 109-124, 2012.

41. Dean EJ, Ranson M, Blackhall F and Dive C: X-linked inhibitor of apoptosis protein as a therapeutic target. Expert Opin Ther Targets 11: 1459-1471, 2007.

42. Mastrangelo E, Vachette P, Cossu F, Malvezzi F, Bolognesi M and Milani M: The activator of apoptosis Smac-DIABLO acts as a tetramer in solution. Biophys J 108: 714-723, 2015.

43. Saraei R, Soleimani M, Movassaghpour Akbari AA, Farshdousti Hagh M, Hassanzadeh A and Solali S: The role of XIAP in resistance to TNF-related apoptosis-inducing ligand (TRAIL) in Leukemia. Biomed Pharmacother 107: 1010-1019, 2018.

44. O'Donnell MR, Abboud CN, Altman J, Appelbaum FR, Arber DA, Attar E, Borate U, Coutre SE, Damon LE, Goorha S, et al: NCCN Clinical Practice Guidelines Acute myeloid leukemia. J Natl Compr Canc Netw 10: 984-1021, 2012.

45. Quiney C, Billard C, Faussat AM, Salanoubat C and Kolb JP: Hyperforin inhibits P-gp and BCRP activities in chronic lymphocytic leukaemia cells and myeloid cells. Leuk Lymphoma 48 1587-1599, 2007.

46. Xu X, Wang Y, Deng H, Liu C, Wu J and Lai M: HMGA2 enhances 5-fluorouracil chemoresistance in colorectal cancer via the Dvl2/Wnt pathway. Oncotarget 9: 9963-9974, 2018.

47. Tan L, Xu H, Chen G, Wei X, Yu B, Ye J, Xu L and Tan H: Silencing of HMGA2 reverses retardance of cell differentiation in human myeloid leukaemia. Br J Cancer 118: 405-415, 2018.

48. Ohshima K, Inoue K, Fujiwara A, Hatakeyama K, Kanto K, Watanabe Y, Muramatsu K, Fukuda Y, Ogura S, Yamaguchi K and Mochizuki T: Let-7 microRNA family is selectively secreted into the extracellular environment via exosomes in a metastatic gastric cancer cell line. PLoS One 5: e13247, 2010.

49. Watanabe S, Ueda Y, Akaboshi S, Hino Y, Sekita Y and Nakao M: HMGA2 maintains oncogenic RAS-induced epithelial-mesenchymal transition in human pancreatic cancer cells. Am J Pathol 174: 854-868, 2009.

50. Lin Y, Meng F, Lu Z, Chen K, Tao Y, Ouyang Y and Cao X: Knockdown of PKM2 suppresses tumor progression in human cervical cancer by modulating epithelial-mesenchymal transition via Wnt/ $\beta$-catenin signaling. Cancer Manag Res 10: 4191-4202, 2018.

51. Yang F, Xiao Z and Zhang S: Knockdown of miR-194-5p inhibits cell proliferation, migration and invasion in breast cancer by regulating the $\mathrm{Wnt} / \boldsymbol{\beta}$-catenin signaling pathway. Int $\mathrm{J}$ Mol Med 42: 3355-3363, 2018.

52. Zhao C, Qiao C, Zong L and Chen Y: Long non-coding RNA-CCAT2 promotes the occurrence of non-small cell lung cancer by regulating the $\mathrm{Wnt} / \beta$-catenin signaling pathway. Oncol Lett 16: 4600-4606, 2018.

53. Liu L, Jiang H, Zhao J and Wen H: MiRNA-16 inhibited oral squamous carcinoma tumor growth in vitro and in vivo via suppressing Wnt $/ \beta$-catenin signaling pathway. Onco Targets Ther 11: 5111-5119, 2018.

54. Kumar R, Kotapalli V, Naz A, Gowrishankar S, Rao S, Pollack JR and Bashyam MD: XPNPEP3 is a novel transcriptional target of canonical Wnt $/ \beta$-catenin signaling. Genes Chromosomes Cancer 57: 304-310, 2018.

55. Qiu F, Shin Y, Chen D, Cheng R, Chen Q, Zhou K, Larrick JW, Mendelson AR and Ma JX: Anti-angiogenic effect of a humanized antibody blocking the $\mathrm{Wnt} / \beta$-catenin signaling pathway. Microvasc Res 119: 29-37, 2018.

56. Zha L, Zhang J, Tang W, Zhang N, He M, Guo Y and Wang Z: HMGA2 elicits EMT by activating the Wnt/ $\beta$-catenin pathway in gastric cancer. Dig Dis Sci 58: 724-733, 2013.

57. Wend P, Runke S, Wend K, Anchondo B, Yesayan M, Jardon M, Hardie N, Loddenkemper C, Ulasov I, Lesniak MS, et al: WNT10B/ $\beta$-catenin signalling induces HMGA2 and proliferation in metastatic triple-negative breast cancer. EMBO Mol Med 5: 264-279, 2013

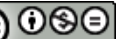

This work is licensed under a Creative Commons Attribution-NonCommercial-NoDerivatives 4.0 International (CC BY-NC-ND 4.0) License. 